\title{
WIEDZA STUDENTÓW INFORMATYKI POLITECHNIKI LUBELSKIEJ O PLATFORMACH E-LEARNINGOWYCH
}

\author{
Magdalena Borys, Edyta Lukasik
}

Politechnika Lubelska, Instytut Informatyki

Streszczenie. W latach 2011-2012 realizowany byt na Wydziale Elektrotechniki i Informatyki (WEiI) Politechniki Lubelskiej projekt POKL „,Absolwent na miare czasu" skierowany do studentów studiów magisterskich kierunku Informatyka. Wśród celów realizowanego projektu ważne miejsce zajmuje utworzona platforma e-learningowa. W niniejszym artykule omówiono obecny stan wykorzystania platformy, zaprezentowano wyniki badań przeprowadzonych wśród studentów dotyczacych: poziomu wiedzy studentów o nauczaniu na odległość, oceny stworzonej platformy oraz przydatności materiałów na niej umieszczonych.

Slowa kluczowe: e-learning, platforma e-learningowa, formy kształcenia

\section{COMPUTER SCIENCE STUDENT AT LUBLIN UNIVERSITY OF TECHNOLOGY KNOWLEDGE OF E-LEARNING PLATFORMS}

Abstract. In 2011-2012 at the Faculty of Electrical Engineering and Computer Science the project called "Graduate of our time" aimed for students of Master studies in Computer Science is realized. One of the most important objectives of the project is implementation of e-learning platform. The article discusses the current state of the use of the platform, presents the results of the survey conducted among students regarding: the level of students knowledge of distance learning, assessment of created platform as well as assessment developed learning resources.

Keywords: e-learning, e-learning platform, learning methods

\section{Wstęp}

Obecnie nauczanie na odległość staje się nieodłącznym elementem studiów na uczelniach wyższych. Jest ono ważnym aspektem, na który zwracają uwagę przyszli studenci. Politechnika Lubelska nie posiadała jeszcze platformy e-learningowej. W latach 2011-2012 realizowany był na Wydziale Elektrotechniki i Informatyki (WEiI) Politechniki Lubelskiej projekt POKL „Absolwent na miarę czasu" skierowany do studentów studiów magisterskich kierunku Informatyka. Wśród celów realizowanego projektu ważne miejsce zajmuje utworzona platforma e-learningowa.

\section{Koncepcja e-learningu na PL}

Nie da się zaprzeczyć stwierdzeniu, iż obecne czasy to pokolenie e-społeczeństwa. Właśnie tworzenie i przetwarzanie informacji, a nie dóbr materialnych, jest jednym $\mathrm{z}$ określeń społeczeństwa informacyjnego (e-społeczeństwa) opartego na wiedzy, mądrości oraz nowoczesnej, ciągle rozwijającej się technologii informacyjnej. Studenci Politechniki Lubelskiej otrzymują szansę korzystania $\mathrm{z}$ narzędzia odpowiedniego na przygotowanie ich do stania się e-obywatelami w e-społeczeństwie. Aby nie byli oni obywatelami, którzy są zagrożeni wykluczeniem cyfrowym, wskazany jest ich kontakt i umiejętność posługiwania się jak najszerszą liczbą nowoczesnych technologii informatycznych [1]. E-obywatel w e-społeczeństwie powinien umieć sobie poradzić $\mathrm{z}$ takimi instytucjami jak e-urzędy, e-banki czy e-sklepy. Dobrym początkiem będzie więc dla każdego $\mathrm{z}$ nich kontakt $\mathrm{z}$ platformą e-learningową. Platforma ta będzie na początku skierowana głównie do studentów studiów dziennych stopnia drugiego na kierunku Informatyka. Korzyści dla uczelni także mają tu swój mocny punkt.

R. Tadeusiewicz wskazał na dwa możliwe kierunki rozwoju e-edukacji. Pierwszy z nich to kształcenie masowe, nastawione na minimalizację kosztów oraz drugi - kształcenie zindywidualizowane, zorientowane na wysoką jakość [2]. Autorzy projektu czyli wykładowcy mają nadzieję, iż stworzona platforma będzie przyczyniać się do realizacji tego drugiego kierunku rozwoju e-edukacji.

\section{Wiedza studentów PL z zakresu e-learningu}

Wśród studentów trzeciego roku studiów inżynierskich oraz pierwszego semestru studiów II stopnia magisterskich została przeprowadzona ankieta dotycząca posiadanej przez nich wiedzy na temat e-learningu. Pytania $\mathrm{w}$ ankiecie dotyczyły: samego pojęcia e-learning, form nauczania zdalnego, znajomości platform e-learningowych już funkcjonujących (na innych uczelniach). Dzięki ankiecie jej autorki chciały poznać opinię studentów dotyczącą oceny efektywności nauczania przez Internet oraz zainteresowania uruchomieniem na macierzystej uczelni platformy e-learningowej. Poniżej omówione zostaną wyniki tej ankiety. W ankiecie brało udział 92 studentów.

Na pytanie dotyczące definiowanego pojęcia odpowiedź była dość optymistyczna, gdyż 80 na 92 ankietowanych odpowiedziało pozytywnie.

Tabela 1. Odpowiedzi ankietowanych na pytanie „Czy wiesz co to jest e-learning?"

\begin{tabular}{|c|c|}
\hline Odpowiedź & Ilość odpowiedzi (\%) \\
\hline Wiem & 87 \\
\hline Mniej więcej wiem & 11 \\
\hline Nie wiem & 2 \\
\hline
\end{tabular}

Kolejne pytanie dotyczyło znajomości innych form nauczania zdalnego. Osiemnaście osób odpowiedziało twierdząco, ale w kolejnym pytaniu tylko jedna osoba wymieniła poprawne formy. Natomiast 10 osób wymieniało takie narzędzia jak: Google czy Wikipedia jako formy nauczania zdalnego, co świadczy o braku wiedzy na temat form nauczania zdalnego.

Jeżeli chodzi o korzystanie z platform e-learningowych innych uczelni, to $10 \%$ ankietowanych korzystało co najmniej jeden raz $\mathrm{z}$ takiej formy pomocy w nauce. To dosyć mała liczba studentów. Ale już ponad połowa ankietowanych stwierdziła, iż korzystała chociaż raz z kursów e-learningowych. Jednak pod znakiem zapytania pozostaje definicja kursu e-lerningowego, jaką posiadają studenci. Tego w pytaniu już nie sprecyzowano. Dokładne odpowiedzi na pytanie dotyczące udziału w kursach e-learingowych pokazano w tabeli 2 .

Tabela 2. Odpowiedzi ankietowanych na pytanie „Czy uczestniczyłaś/eś w jakimś kursie e-learningowym?"

\begin{tabular}{|c|c|}
\hline Odpowiedź & Ilość odpowiedzi (\%) \\
\hline Tak & 59 \\
\hline $\mathrm{Nie}$ & 41 \\
\hline
\end{tabular}

Tabela 3. Odpowiedzi ankietowanych na pytanie „,Czy uważasz, że forma nauki poprzez platformę e-learningowa daje dobre rezultaty?"

\begin{tabular}{|c|c|}
\hline Odpowiedź & Ilość odpowiedzi (\%) \\
\hline Tak & 8 \\
\hline $\begin{array}{c}\text { Tak, ale tylko przy dużym } \\
\text { zaangażowaniu ucznia }\end{array}$ & 67 \\
\hline Nie wiem & 21 \\
\hline Nie & 4 \\
\hline
\end{tabular}


Bardzo ważnym dla przeprowadzających ankietę było pytanie o efektywność nauki przy wykorzystaniu platformy e-learningowej. Nastawienie studentów wyraźnie uwypukliło tutaj aspekt przełożenia dużej części nauki na uczącego się. Aż 67\% ankietowanych wskazało tę formę nauki, jako dającą dobre rezultaty, ale tylko przy dużym zaangażowaniu własnym studenta (tabela 3). Jest to często powtarzany element kursów e-learningowych. Tylko świadomy tego i zdolny do samodyscypliny student jest $\mathrm{w}$ stanie skorzystać $\mathrm{z}$ takiej formy nauki.

Ostatnie pytanie dotyczyło uruchomienia platformy na Politechnice Lubelskiej. Cieszy fakt, iż prawie $90 \%$ ankietowanych, a dokładnie $89 \%$, chciało tego typu przedsięwzięcia na ich uczelni.

\section{Miejsce platformy w procesie edukacji}

Na kierunku Informatyka na WEiI PL w ramach Priorytetu IV realizowany jest projekt, którego jednym $\mathrm{z}$ efektów ma być uruchomienie wirtualnego kampusu, w skład którego wchodzi m.in. platforma e-learningowa. Do realizacji platformy e-learningowej zostało wybrane oprogramowanie Moodle (Modular Object Oriented Dynamic Learning Enviroment) w wersji 2.0.2 udostępniane na licencji GNU GPL [3]. Platforma ta została udostępniona pod adresem internetowym http://moodle.cs.pollub.pl.

Uruchomiona $\mathrm{w}$ ramach projektu platforma e-learningowa będzie stanowić dla pewnej grupy studentów możliwość wyrównania wiedzy. Umieszczone na niej materiały będą uzupełnieniem zajęć odbywających się $\mathrm{w}$ formie tradycyjnej. Chodzi o studentów słabszych lub mających zaległości spowodowane np. nieobecnościami. Materiały na platformę będą przygotowywać wykładowcy danych przedmiotów prowadzący je $\mathrm{w}$ formie tradycyjnej. Nie ma więc niebezpieczeństwa, iż materiały na platformie i przekazane w salach wykładowych będą się dublowały albo znacznie odbiegały tematycznie od siebie. Kursy tutaj umieszczone będą kontynuacją zajęć przewidzianych programem nauczania na danych kierunku. Pewne zagadnienia będą wyjaśnione dogłębniej, będzie więcej ćwiczeń na temat przerabianych zagadnień. O tego typu zastosowaniach e-learningu pisał R. Tadeusiewicz już w 2005 roku [4].

Platforma ta będzie także dawała możliwości zdobycia studentom certyfikatów zewnętrznych. W ramach rozszerzeń konkretnych przedmiotów, umieszczonych na tej platformie, studenci będą mogli doprecyzować obszary wiedzy potrzebne do egzaminów z tych przedmiotów, które będą dawać im certyfikaty. Niewątpliwie zwiększy to wartość studentów na rynku pracy.

$\mathrm{Na}$ koniec listopada 2012 konta w systemie posiadało 675 studentów kierunku Informatyka I i II stopnia oraz 40 wykładowców realizujących przedmioty na kierunku Informatyka. Ponadto łączna liczba kursów wynosi 149.

W ramach projektu opracowane zostały dwa rodzaje materiałów dydaktycznych, które zostały umieszczone na platformie e-learningowej.

Pierwszy rodzaj stanowią materiały wykładowe oraz materiały do ćwiczeń, laboratoriów oraz zajęć projektowych. Materiały te, w postaci plików w formacie PDF, zostały pogrupowane według przedmiotów i umieszczone jako zasoby kursów na platformie. Dostęp studentów do poszczególnych kursów, a tym samym materiałów, został zrealizowany na zasadzie samodzielnej rejestracji z kluczem dostępu, który studenci otrzymują od wykładowców w czasie zajęć tradycyjnych.

Drugi rodzaj materiałów dydaktycznych stanowią kursy e-learningowe. Większość autorów zdecydowała się na stworzenie kursu w standardzie SCORM przy wykorzystaniu programu eXe Learning [5]. Obecnie na platformie umieszczonych jest 60 kursów e-learningowych.

Platforma e-learningowa została także wykorzystana do rejestracji oraz umieszczania materiałów $\mathrm{z}$ innych aktywności w projekcie, takich jak: seminaria międzynarodowe, warsztaty prowadzone przez przedstawicieli przemysłu, zajęcia warsztatowe $\mathrm{z}$ umiejętności miękkich czy doradztwo personalne.
Dodatkowo na platformie znajdują się materiały do zajęć dydaktycznych dla studentów studiów I stopnia na kierunku Informatyka.

\section{Opinie studentów na temat platformy}

Po trzech semestrach korzystania z platformy jej użytkownicy (studenci) zostali zapytani o ocenę samej platformy, jak i korzyści $\mathrm{z}$ jej istnienia. Udział $\mathrm{w}$ ankiecie wzięło 95 studentów pięciu uruchomionych specjalności. Autorów interesowało miejsce, z którego korzystają z platformy. Ponad połowa ankietowanych korzysta z platformy poza zajęciami, co należy uznać za całkiem pozytywny wynik.

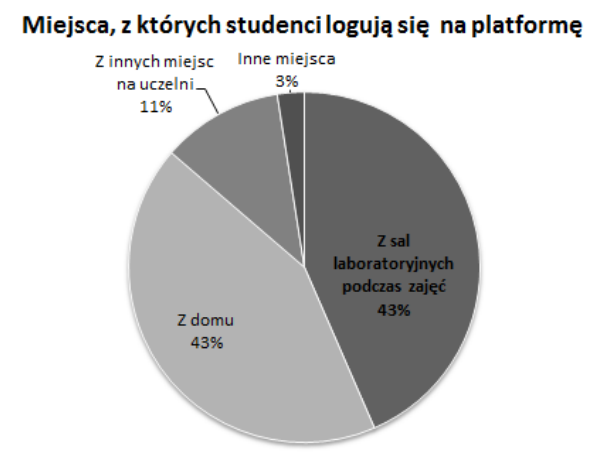

Rys. 1. Odpowiedzi ankietowanych na pytanie o miejsce logowania

Następne pytanie dotyczyło celu, w jakim studenci logują się na platformę.

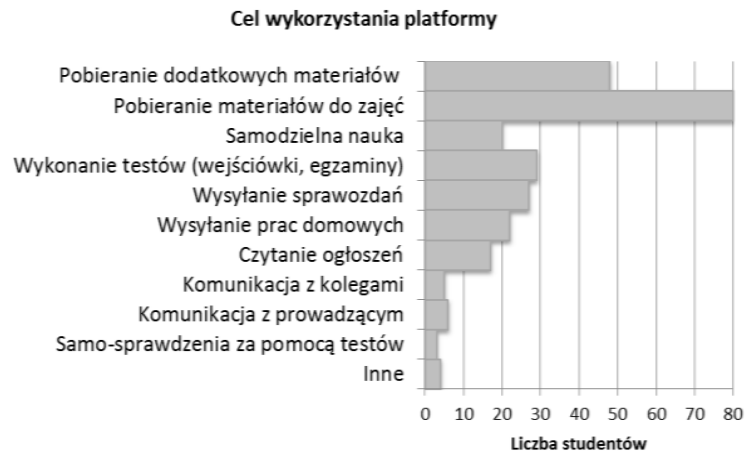

Rys. 2. Odpowiedzi ankietowanych na pytanie o cel wykorzystania platformy

Przeciętna liczba kursów, na które student jest zapisany to 6-7 kursów. Ocena tych kursów przez ich uczestników jest dość przychylna dla ich autorów, a co za tym idzie najważniejszy cel uruchomienia platformy został osiągnięty. Studenci chętnie sięgają do materiałów umieszczonych na platformie.

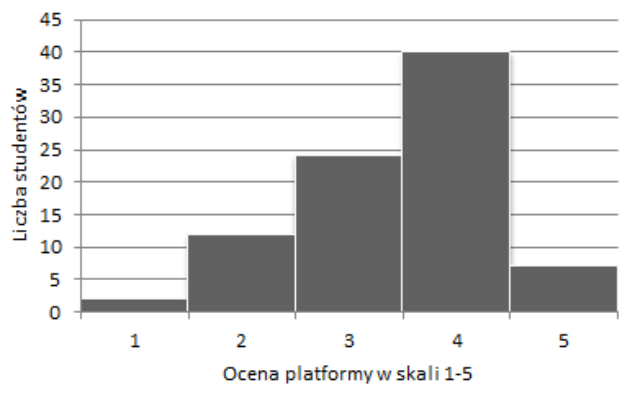

Rys. 3. Ocena funkcjonalności platformy

Ocena funkcjonalności platformy wypadła dosyć korzystnie dla Wydziału. Zdaniem studentów, a jest ono kluczowe dla uczelni, funkcjonalność platformy uzyskała średnią ocenę 3,5; przy czym $8 \%$ wystawiło noty bardzo dobre i $47 \%$ dobre. Pelna skala ocen pokazana została na wykresie na rys. 3 . 


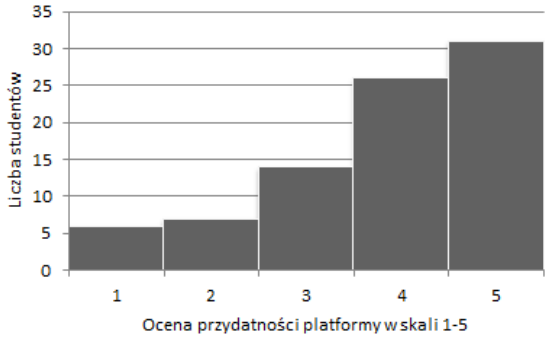

Rys. 4. Ocena przydatności platformy

Studenci docenili przydatność platformy w trakcie procesu kształcenia, co ukazano na rys. 4 . Wystawienie $36 \%$ ocen bardzo dobrych i $31 \%$ dobrych jest wynikiem zadowalającym.

\section{Wykorzystanie platformy}

W terminie od 1 października 2011 do 30 września 2012 roku z materiałów umieszczonych na platformie skorzystało bardzo wielu studentów kierunku Informatyka. $\mathrm{Na}$ wykresie przedstawionym na rys. 5 zaprezentowano średnią dzienną liczbę logowań do systemu. Wyraźnie widać, iż zwiększona aktywność studentów jest w czasie zaliczeń końcowych przedmiotów i tuż przed sesją - styczeń oraz w sesji poprawkowej- marzec. Wynika więc $\mathrm{z}$ tej analizy jasno, iż w czasie natężonej nauki samodzielnej studenci chętnie sięgają do stworzonych dla nich dodatkowych materiałów będących źródłem wiedzy, nie poprzestają jedynie na samych wykładach i laboratoriach.

Wyniki zaprezentowane wyraźnie wskazują na fakt, iż platforma e-learningowa jest potrzebna na uczelni, studenci nie mają oporów by korzystać $\mathrm{z}$ zamieszczonej na niej wiedzy. Oszczędza im to czas na jej szukanie oraz stwarza dogodne warunki nauki w domu wypływające $\mathrm{z}$ zastosowania e-learningu.

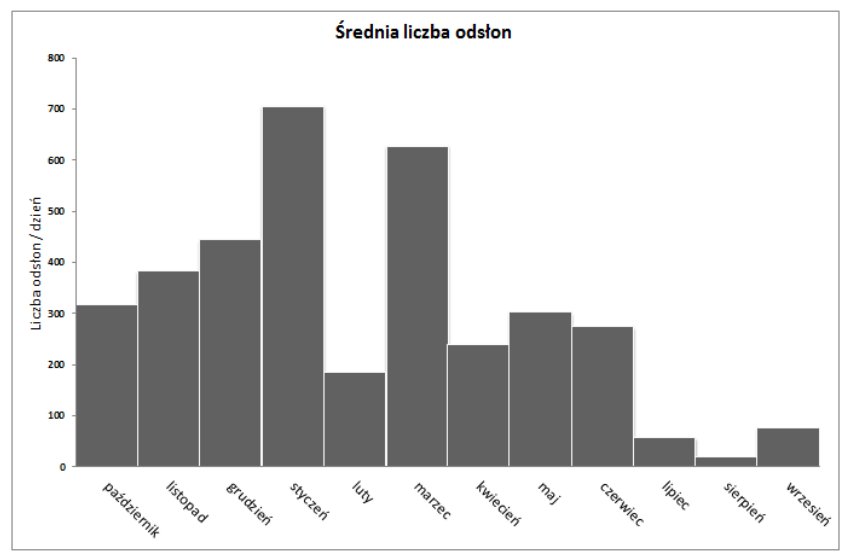

Rys. 5. Wykorzystanie platformy od 01.10.2011 do 30.09.2012

Wśród materiałów do samodzielnej nauki umieszczonych na platformie największą popularnością cieszyły się kursy dotyczące bardzo aktualnych i ważnych zagadnień $\mathrm{w}$ technologiach informatycznych. Zostały one połączone $\mathrm{w}$ grupy tematyczne i przedstawione na rys. 6 .

\begin{tabular}{|c|c|}
\hline $\begin{array}{c}\text { Architektura Zorientowana na } \\
\text { Serwisy }\end{array}$ \\
$\begin{array}{c}\text { Systemy Baz Danych } \\
\text { Bustownie Danych i Systemy Intelligence } \\
\text { Administrowanie Bazami Danych }\end{array}$ & $\begin{array}{c}\text { Obiektowe projektowanie } \\
\text { systemów informatycznych }\end{array}$ \\
\hline
\end{tabular}

Wśród materiałów, z których najczęściej korzystali studenci są przedmioty z obu specjalności, które są uruchomione na drugim stopniu studiów na Informatyce na Politechnice Lubelskiej tj. Aplikacje Internetowe oraz Technologie Wytwarzania Oprogramowania. Podane przedmioty są kluczowymi zarówno dla kierunku, jak i specjalizacji. Program kształcenia dla tych przedmiotów został opracowany we współpracy $\mathrm{z}$ przedstawicielami przemysłu $\mathrm{w}$ oparciu o potrzeby regionu i branży IT, dlatego też przedmioty te decydują o jakości kształcenia na obydwu specjalnościach, a także definiują główne kompetencje absolwenta tych specjalności. Bardzo pozytywne jest zjawisko, że w dobie cyfryzacji i nieograniczonego dostępu do różnych źródeł ,wiedzy” student wybiera to pewne, które firmuje jego uczelnia i wykładowcy.

\section{Podsumowanie}

Uruchomienie platformy e-learningowej, służącej jako wsparcie nauczania tradycyjnego, niewątpliwie jest docenione przez korzystających z niej studentów.

Obecnie możliwość dopasowania sobie czasu i miejsca nauki jest bardzo cenna, dlatego tego typu formy nauki zyskują w oczach uczących się. Chęć studentów do poszerzania wiedzy zdobytej na zajęciach kontaktowych $\mathrm{z}$ wykładowcami jest dość duża, czego wyrazem jest korzystanie z kursów poświęconych wysoce specjalistycznej wiedzy związanej z kierunkiem studiów. Mają oni dzięki temu wpływ na kształtowanie swojej wiedzy i kompetencji. Zadaniem uczelni jest stworzenie takiej możliwości poprzez uruchomienie platformy e-learningowej i umieszczenie na niej interesujących i przydatnych materiałów.

\section{Literatura}

[1] Chodacka B., Miłosz M.: E-obywatel - przezwyciężanie barier. E-mentor nr 2(24)/2008.

[2] Tadeusiewicz R.: Dwa cele i dwa modele e-learningu. Materiały z konferencji E-learning w Społeczeństwie Wiedzy, AGH, Kraków, 2005.

[3] Tadeusiewicz R.: E-learning szansą wzbogacenia oferty edukacyjnej Uczelni, BIP AGH 38 - luty 2005, http://www.biuletyn.agh.edu.pl/archiwum_bip/ archiwum_bip_pdf/pdf_138/04_138.pdf [20.10.2012].

[4] Dokumentacja Exe Learning, http://exelearning.org [15.05.2012]

[5] Dokumentacja Moodle, http://moodle.org [18.10.2012].

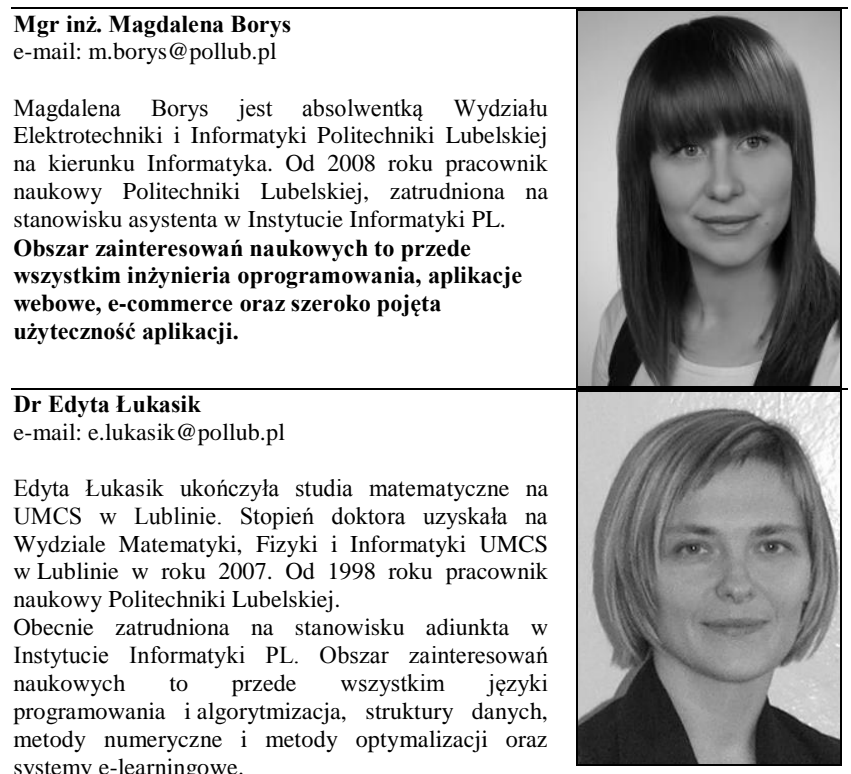
systemy e-learningowe.

otrzymano/received: 23.02.2014 przyjęto do druku/accepted: 30.03 .2014 